\title{
Małżeństwo w projektach dokumentów na Wszechprawosławny Sobór
}

\author{
ks. Andrzej Kuźma \\ Chrześcijańska Akademia Teologiczna w Warszawie \\ Polska \\ akuzma65@wp.pl
}

Fr. Andrzej Kuźma, The Sacrament of Marriage in the draft documents of Great and Holy Synod, Elpis, 18 2016: 177-182.

\begin{abstract}
This article analyses the text of the draft document for the upcoming Great and Holy Synod entitled: „The Sacrament of Marriage and Its Impediments." This document is one of the six topics that will be addressed by future Synod. The first version of this document was accepted in 1982, however the final draft text was significantly expanded and approved by the Synaxis of the Primates in January 2016.

Streszczenie: $\mathrm{W}$ artykule został poddany analizie tekst projektu dokumentu na zbliżający się Sobór Wszechprawosławny: „Sakrament małżeństwa i przeszkody do jego zawarcia”. Dokument jest jednym z sześciu punktów, którymi zajmie się przyszły Sobór. Pierwsza wersja omawianego dokumentu została przyjęta w 1982 r. natomiast ostateczny tekst projektu znacząco rozszerzony został zatwierdzony przez Zgromadzenie Zwierzchników w styczniu $2016 \mathrm{r}$.
\end{abstract}

Keywords: Great and Holy Synod, The Sacrament of Marriage draft document, impediments of marriage.

Słowa kluczowe: Sobór Wszechprawosławny, dokument o małżeństwie, przeszkody w zawarciu związku małżeńskiego.

Wśród sześciu tematów, które zostały przygotowane jako projekty na Wszechprawosławny Sobór, który odbędzie się w czerwcu bieżącego roku na wyspie Kreta w Grecji, znajduje się również dokument: „Sakrament małżeństwa i przeszkody do jego zawarcia"1. Tematyka dotycząca zagadnienia małżeństwa pojawiła się już na początku procesu przygotowawczego omawianego Soboru. Na pierwszej Ogólnoprawosławnej Konferencji Przedsoborowej w 1976r. w Chambésy k. Genewy, temat dotyczący małżeństwa znalazł się w na szóstym miejscu w dziesięciopunktowym katalogu tematów, którymi powinien zając się przyszły Sobór². Był też jednym z pierwszych tematów, które zostały opracowane i przyjęte przez kolejną Ogólnoprawosławną Konferencję Przedsoborową jako projekt dokumentu na przyszły Wszechprawosławny Sobór, która odbyła się w 1982 r. w Chambésy. Dokument nosił krótki tytuł: „Przeszkody małżeńskie”’. W swoim zamiarze więc autorzy tego do-

\footnotetext{
Dokument ten dostępny jest $\mathrm{w}$ dwóch wersjach tłumaczeniowych na j. polski: 1) Sakrament małżeństwa i przeszkody do jego zawarcia, tłum. T. Kałużny [w:] Przed Soborem Wszechprawosławnym, Redakcja T. Kałużny, Z. Kijas, Kraków 2016, s. 267-271, 2) Sakrament małżeństwa i jego przeszkody, (Dokument uzgodniony przez uczestników Synaksy Zwierzchników Cerkwi Prawosławnych w Chambésy 21-28 stycznia 2016), tłum. J. Charkiewicz, J. Betlejko, A. Kuźma [w:] Wiadomości PAKP 2016, nr 5 (318), s. 14-15. Pierwsza wersja tłumaczeniowa posiada bardziej charakter naukowy, natomiast druga kierowana jest do wiernych Kościoła prawosławnego w Polsce jako materiał informacyjny. Dlatego też $\mathrm{w}$ artykule zostanie użyta pierwsza wersja tłumaczeniowa.

2 Zob. Synodica III, Secretariat pour la preparation du Saint et Grande Concile de l'Eglise Orthodoxe, Chambésy- Genève 1979. s. 114.

3 Tłum. pol. T. Kałużny, Przeszkody małżeńskie, Tekst przyjęty przez II Ogólnoprawosławną Konferencję Przedsoborową (Chambesy 1982) [w:] T. Kałużny, Nowy Sobór Ogólnoprawosłąny, Kraków 2008, s. 398-399.
}

kumentu w jego pierwotnej wersji wskazywali jedynie na istniejące problemy związane z przeszkodami do zawarcia związku małżeńskiego. Proces przygotowawczy do Soboru ciągnął się jednak latami i kiedy w 2014 r. w Konstantynopolu odbyło się spotkanie wszystkich Zwierzchników Lokalnych Autokefalicznych Kościołów Prawosławnych (Synaxa), stwierdzono, że część dokumentów, które już zostały wcześniej przyjęte i zatwierdzone jako projekty na przyszły Sobór, uległy dezaktualizacji, lub też potrzebują większych lub mniejszych zmian. Dokument „Przeszkody małżeńskie" został zakwalifikowany do tej, grupy gdzie wprowadzone zmiany miały być niewielkie ${ }^{4}$. Wprowadzenie zmian zostało powierzone Specjalnej Komisji, która została powołana na tymże spotkaniu zwierzchników i zajęła się ich wprowadzaniem i korektą na przełomie 2014/2015r. ${ }^{5}$. Dokument dotyczący małżeństwa stał się obiektem dyskusji dopiero w czasie trzeciego spotkania Komisji (29 marca-4 kwietnia 2015).

W momencie kiedy Komisja przystąpiła do rozpatrywania i wprowadzania poprawek $\mathrm{w}$ dokumencie, stwierdzono znaczące braki w tym tekście. $\mathrm{W}$ opinii większości przedstawicieli lokalnych Kościołów prawosławnych, taką główną niedoskonałością dokumentu było brak jednoznacznego i pozytywnego podejścia do instytucji małżeństwa a co zatem idzie i do rodziny. W obecnych czasach,

\footnotetext{
4 Zob. Decyzja Zwierzchników Cerkwi Prawosławnych, Wiadomości PAKP 2014, nr 4(293) s.3.

5 Komisja spotkała się trzykrotnie w Centrum Patriarchatu Ekumenicznego w Chambésy k. Genewy: pierwsze spotkanie odbyło się w dniach 29 września- 4 października 2014; drugie 15-21 lutego 2015; trzecie 29 marca- 3 kwietnia 2015.
} 
kiedy do instytucji małżeństwa i rodziny podejście staje się coraz bardziej liberalne i często sprzeczne z normą chrześcijańską nie wystarczy mówić jedynie o przeszkodach w zawarciu związku małżeńskiego, lecz należy podkreślić wartość i ważność tych tak mocno związanych ze sobą instytucji. Z tego jednak względu, że zebranie Zwierzchników Lokalnych Kościołów Prawosławnych w marcu 2014 r. określiło, iż omawiany dokument powinien w niewielkim stopniu zostać uaktualnionym, bez wnoszenia znaczących korekt, przewodniczący Komisji specjalnej, Metropolita Pergamonu Jan (Ziziulas) nie zgodził się aby proponowane rozszerzenie dokumentu miało miejsce ${ }^{6}$. Dokument dotyczący małżeństwa został jednak znacząco zmieniony i rozszerzony na kolejnym spotkaniu Zwierzchników Lokalnych Kościołów Prawosławnych, które miało miejsce w styczniu 2016 r. w Chambésy k. Genewy ${ }^{7}$. Wprowadzono cały rozdział wyrażający pojmowanie małżeństwa jako fundamentu rodziny w Kościele prawosławnym. W ten sposób po Synaksie Zwierzchników w styczniu 2016 r. dokument o małżeństwie stał się oficjalnym projektem dokumentu na Wszechprawosławny Sobór z nowym tytułem: „Sakrament małżeństwa i przeszkody do jego zawarcia”.

Dokument zasadniczo składa się z dwóch części, pierwsza: „Prawosławne małżeństwo”, i druga: „Przeszkody małżeńskie”. Przy czym druga część stanowi w przeważającej mierze powtórzenie założeń, które zostały wyrażone w starej wersji tekstu przyjętego w 1982 r.

Już na początku analizowanego tekstu zauważalny jest wpływ toczącej się dyskusji wokół potrzeby oficjalnego wyrażenia, które stawałoby w obronie małżeństwa i instytucji rodziny we współczesnym świecie wynikającego ze zjawiska sekularyzacji i relatywizmu moralnego. Dokument zaczyna się słowami: „Instytucja rodziny jest obecnie zagrożona w związku ze zjawiskiem sekularyzacji, jak również relatywizmu moralnego. Kościół prawosławny uznaje świętość małżeństwa za istotny i niezaprzeczalny element swojego nauczania” (I.1) ${ }^{8}$. Nazywając małżeństwo świętością, autorzy dokumentu pragną podkreślić jego biblijne pochodzenie, gdzie wyraźnie świadectwo znajdujemy w Piśmie Świętym. Małżeństwo swoją instytucję i ustanowienie opiera na biblijnym fundamencie stworzenia pierwszych ludzi, Adama i Ewy (Rdz 2,23). „Od samego początku związek ten postrzegany był nie tyko jako duchowa wspólnota małżeńskiej pary (mężczyzny i kobiety), lecz także jako możliwość zabezpieczenia przedłużenia rodzaju ludzkiego" (I,2). Pobłogosławione małżeństwo w raju, otrzymuje też swój wymiar sakramentalny w Nowym Te-

\footnotetext{
Zob. A. Kuźma, Trzecie spotkanie Komisji Przygotowawczej, Wiadomości PAKP 5 (306) 2015 s. 7.

Komisja specjalna nie miała takich uprawnień aby wykonywać zadania ponad tymi które zostały jej powierzone przez Zebranie Zwierzchników (marzec 2014). Natomiast Zebranie Zwierzchników, którzy obradowali w styczniu 2016 r. takie kompetencje posiadali. Zob. Synaksa Zwierzchników Lokalnych Cerkwi Prawosławnych, Chambésy (21-28 stycznia 2016), Wiadomości PAKP 3 (316) 2016, s. 4.

8 Tłumaczenie, które jest wykorzystane w niniejszym artykule: T. Kałużny, Sakrament małżeństwa i przeszkody do jego zawarcia"[w:] Przed Soborem Wszechprawosławnym, Redakcja T. Kałużny, Z. Kijas Kraków 2016, s. $267-271$.
}

stamencie poprzez uczynienie „pierwszego znaku” przez Jezusa Chrystusa na weselu w Kanie Galilejskiej przemieniając wodę w wino $(\mathrm{J} 2,11)$. Ten sakramentalny charakter małżeństwa zyskuje niezwykle wysoki walor w Nowym Testamencie, gdzie związek mężczyzny i kobiety porównywany jest do związku Chrystusa z Kościołem. Autorzy dokumentu nie omieszkali posłużyć się tym porównaniem dla podkreślenia rangi i świętości małżeństwa: „Sakrament nierozerwalnej jedności między mężczyzną i kobieta jest obrazem zjednoczenia Chrystusa i Kościoła (Ef. $5,32)$ " (I,2). Praktycznie od pierwszych wieków istnienia Kościoła, małżeństwu nadawano charakter Chrystocentryczny. Świadczą o tym słowa św. Ignacego Antiocheńskiego (+107), który nawołuje do tego aby małżeństwo było zawierane „za zgodą biskupa, tak by małżeństwo było zawarte w Panu, a nie według ludzkiej pożądliwości. Niechaj wszystko dokonuje się na chwałę Bożą"9 (I,3). Słowa św. Ignacego świadczą, o tym, że Kościół praktycznie od początku brał udział w wydarzeniu jakim jest zawarcie związku małżeńskiego członków Kościoła. Zawsze odnosił się z czcią do małżeństwa i szanował jego czystość i świętość $(\mathrm{I}, 3)$.

Zsyłając się na wyrażenia Klemensa Aleksandryjskiego, małżeństwo w dokumencie nazywane jest Małym Kościołem: „Kimże zaś są ci dwaj lub trzej zebrani w imię Chrystusa, pośród których jest obecny Pan? Czyż nie są to mężczyzna, kobieta i dziecko zjednoczeni w Bogu?"10. Indywidualne istnienie człowieka poprzez sakrament małżeństwa podnoszone jest na wyższy stopień, dlatego, że „wspólnota przewyższa indywidualne istnienie i wprowadza ich w porządek życia według obrazu królestwa Przenajświętszej Trójcy" (I,4). Niemniej jednak warunkiem takiego życia na obraz św. Trójcy jest wspólna wiara narzeczonych w Syna Bożego: „Niezbędnym warunkiem wstępnym do małżeństwa jest wiara w Jezusa Chrystusa, wiara, którą wspólnie powinni wyznawać narzeczony i narzeczona (mężczyzna i kobieta)" $(\mathrm{I}, 4)$.

Sakrament małżeństwa wiążący dwoje ludzi staje się początkiem rodziny i to właśnie rodzina (instytucja rodziny) „pozwala promieniować wspólnocie małżonków zarówno w Kościele jak i w całym społeczeństwie” (I,5). Dlatego też wychowanie dzieci może przebiegać wyłącznie w rodzinie, „tylko ona może zapewnić ochronę i wychowanie dzieci, zarówno w duchowej misi Kościoła, jak i w społeczeństwie” (I,5).

Zasada kościelności małżeństwa i jego wymiar biblijny nakłada pewne wymogi religijne na osoby, które wstępują w taki związek. Wymogi te w większości odpowiadają zasadom, które przyświecają ustawodawstwu cywilnemu (różnica płci, odpowiedni wiek itp.). Są też wymogi, które w ustawodawstwie cywilnym nie mają znaczenia, nato-

\footnotetext{
Zob. Ignacy Antiocheński, List do Polikarpa, V,2 tłum. pol. A. Świderkówna[w:] Pierwsi świadkowie, pisma Męzów apostolskich, opracowanie ks. M. Starowieyski, Kraków 1998, s. 141.

10 Klemens Aleksandryjski, Kobierce, 3,10 tłum. J. Niemirska-Pilszcyńska, Warszawa 1994, s. 267. W literaturze prawosławnej bardzo często określa się małżeństwo mianem Małego Kościoła, zob. M. Laroche, Mały Kościół, mistyczna przygoda małżeństwa, Hajnówka 2016
} 
miast $\mathrm{w}$ wymiarze kościelnym mogą stanowić przeszkodę do zawarcia związku małżeńskiego (pokrewieństwo duchowe, różnica wyznaniowa lub religijna). Dlatego też w dokumencie zwraca się uwagę na złożoność i delikatność tego problemu w jego rozwiązywaniu: „Duszpasterska delikatność jest niezbędna nie tylko dlatego, że tradycja biblijna potwierdza więź małżeńską z tajemnicą Kościoła, lecz i ze względu na to, że praktyka kościelna nie wyklucza przyjęcia pewnych zasad prawa naturalnego grecko-rzymskiego, które wskazują na małżeństwo jako $<<$ wspólnotę prawa boskiego i ludzkiego >> (Modestyn) i są do pogodzenia ze świętością przypisywaną przez Kościół sakramentowi małżeństwa" (I,6). Zadanie ochrony małżeństwa i instytucji rodziny wymaga aktywności i wyczucia pasterskiego ze strony pasterzy Kościoła: „biskupi i duszpasterze powinni aktywnie rozwijać pracę duszpasterską, aby po ojcowsku chronić wierzących, spierając ich, by umocnili soją nadzieję (...), przez budowanie instytucji rodziny na trwałych fundamentach" (I,7).

Rodzina jest podstawową komórką, która zapewnia ochronę i wychowanie dzieci dlatego też $\mathrm{w}$ dokumencie w wyraźny sposób wskazuje się na istnienie tzw. „Związków partnerskich". Projekt dokumentu stwierdza, że stanowią one swego rodzaju zagrożenie: „We współczesnym świecie realnym zagrożeniem dla chrześcijan prawosławnych jest nacisk w celu uznania nowych form współżycia (partnerstwa). Pogłębiający się kryzys małżeństwa i rodziny budzi głęboki niepokój Kościoła prawosławnego nie tylko z powodu konsekwencji dla społeczeństwa, lecz również $\mathrm{z}$ powodu zagrożenia dla wewnętrznych relacji $\mathrm{w}$ łonie tradycyjnej rodziny. Głównymi ofiarami tych tendencji są małżeńskie pary, a przede wszystkim dzieci” $(\mathrm{I}, 8)$.

Autorzy dokumentu zwracają uwagę na pewną różnicę $\mathrm{w}$ pojmowaniu związku małżeńskiego o charakterze sakramentalnym i charakterze cywilnym: „Cywilny związek małżeński między mężczyzną i kobietą zarejestrowany zgodnie z prawem nie ma charakteru sakramentalnego i jako usankcjonowane prawem współżycie różni się od małżeństwa pobłogosławionego przez Boga i Kościół. Członkowie Kościoła, którzy zawierają cywilny związek małżeński, powinni być traktowani z duszpasterską odpowiedzialnością, która jest niezbędna do tego, by rozumieli oni znaczenie sakramentu małżeństwa i związanego z nim błogosławieństwa" (I,9). W dokumencie nie ma jednoznacznego stwierdzenia, że Kościół uznaje takie związki za ważne, czy też nie uznaje ich ważności. Wyrażenia by „traktować, tych którzy zawierają (jedynie) cywilny związek małżeński z duszpasterską odpowiedzialnością" wskazywałyby, że takie związki są akceptowane. Natomiast, w przypadku, jeśli oboje małżonkowie są wyznania prawosławnego tę "duszpasterską troskę" należałoby rozumieć wydaje się, jako zachęcanie do zawarcia związku sakramentalnego. Są jednak przypadki, kiedy zawarcie związku sakramentalnego jest niemożliwe. Chodziłoby tu o związek małżeński z osobą niewierzącą, agnostykiem, lub osobą nieochrzczoną i często należącą do innej religii (buddystą, muzułmaninem, żydem). Kościół prawosławny nie udziela związków sakramentalnych osobom należącym do innych religii ${ }^{11}$. W takim przypadku małżeństwo cywilne pozostaje jedyną formą świadczącą o zawarciu związku ${ }^{12}$.

Projekt dokumentu na Wszechprawosławny Sobór w kilku miejscach precyzuje, że jeśli mowa jest o związku dwojga ludzi zawsze chodzi o związek mężczyzny i kobiety, umieszczając takie doprecyzowanie po głównym tekście w nawiasach (zob. I, 2; I,4). Należałoby wnioskować, że autorzy tego dokumentu w szczególny sposób chcą uczulić na problem związków homoseksualnych. W punkcie 10 pierwszej części dokumentu w wyraźny sposób podkreślają, że Kościół nie może uznawać i udzielać swego błogosławieństwa osobom tej samej płci: „Kościół nie uznaje zawierania przez swoich członków związków partnerskich jednej płci a także jakiejkolwiek formy partnerstwa innej niż małżeństwo” $(\mathrm{I}, 10)$ dodając: „Kościół powinien dołożyć wszelkich możliwych starań, by ci spośród jego członków, którzy są zaangażowani w takie związki, mogli zrozumieć prawdziwy sens pokuty i pobłogosławionej przez Kościół miłości” $(\mathrm{I}, 10)$.

$\mathrm{W}$ dokumencie zwraca się również uwagę i wyraża troskę wobec wzrastającej liczby rozwodów. Jest to współczesny problem, który stanowi ogromne wyzwanie dla pasterzy Kościoła: „Poważne konsekwencje obecnego kryzysu instytucji małżeństwa i rodziny znajdują swój wyraz we wzroście liczby rozwodów, aborcji (...). Konsekwencje te stanowią wielkie wyzwanie dla misji Kościoła we współczesnym świecie $(\mathrm{I}, 11)$.

Druga część dokumentu omawia przeszkody w zawarciu małżeństwa. W większości powtórzone zostały te punkty, które zawarte były w dokumencie przyjętym przez II Konferencję Ogólnoprawosławną (1982). Niektóre z tych punktów zostały nieco zmodyfikowane i przeformułowane. Jako pierwsze przeszkody w zawarciu związku małżeńskiego ukazane zostały powody wynikające z pokrewieństwa, powinowactwa i adopcji. Dokument jednak nie wyraża w jasny sposób od jakiego stopnia pokrewieństwa związek małżeński może być zawarty bez żarnych przeszkód, stwierdza jedynie, że w tej kwestii „zastosowanie mają przepisy kanonów ( 53 i 54 Soboru Trulliańskiego) i zgodna z nimi praktyka kościelna" (II,1). Problem polega na tym, że kanony nie ukazują konkretnie o jaki stopień pokrewieństwa lub powinowactwa chodzi. W praktyce kościelnej jednak

\footnotetext{
Omawiany dokument porusza to zagadnienie w punkcie II, 5,b

12 Kwestia małżeństw mieszanych, gdzie jedna strona jest wyznania prawosławnego, druga natomiast nie jest chrześcijaninem była szeroko dyskutowana w 1982 r. na II Ogólnoprawosławnej Konferencji Przedsoborowej w czasie przygotowań dokumentu o przeszkodach w zawarciu związku małżeńskiego. Uczestnicy tego spotkania byli zgodni co do tego, że Kościół prawosławny nie może błogosławić związków małżeńskich, gdzie druga strona nie jest chrześcijaninem. Jednocześnie przedstawiciele patriarchatu Antiocheńskiego i Moskiewskiego, zwracali uwagę, że osoba wyznania prawosławnego, która zawarła związek cywilny z niechrześcijaninem (muzułmaninem, żydem, agnostykiem itp.), nie może być traktowana jako osoba żyjąca w cudzołóstwie i poza związkiem małżeńskim. Tym samym nie może być pozbawiona prawa uczestnictwa w życiu sakramentalnym Kościoła. Tzn. nie można takiej osobie zabraniać przystępowania do św. Eucharystii. Wydaje się, że taka opinia była podzielana przez pozostałych członków tego zebrania. Zob. Synodica VIII, Secretariat pour la preparation du Saint et Grande Concile de l'Eglise Orthodoxe, Chambésy- Genève 1994, s. 127-128.
} 
w większości Kościołów lokalnych zezwala się na małżeństwo poczynając od piątego stopnia pokrewieństwa. Do zawarcia jednak małżeństwa przez nupturientów będących w piątym lub szóstym stopniu pokrewieństwa potrzebna jest zgoda biskupa ${ }^{13}$. W kolejnych stopniach taka zgoda jest już niepotrzebna. W niektórych Kościołach lokalnych, jak się okazuje nie zezwala się na zawarcie związku osobom będącym w piątym stopniu pokrewieństwa, lecz zezwala się za zgodą biskupa na zawarcie związku małżeńskiego osobom od szóstego stopnia pokrewieństwa ${ }^{14}$. Dlatego też projekt dokumentu nie wskazuje wyraźnie stopnia pokrewieństwa od którego zezwala się na zawarcie związku, a jedynie zsyła nie na kanony Soboru Truliańskiego dodając: „Praktyka stosowana obecnie w lokalnych Kościołach prawosławnych została określona i ukazana w statutach i odpowiednich decyzjach synodów każdego z tych Kościołów" (II,1). Tym samym na poziomie ogólnoprawosławnym, nie udało sią określić jednoznacznie stosunku do przeszkód w zawarciu związku małżeńskiego wynikających z pokrewieństwa i powinowactwa. Regulację tego zagadnienia pozostawia się gestii lokalnych soborów i synodów.

Kolejna przeszkoda dotyczy drugiego i trzeciego małżeństwa ${ }^{15}$. Takiego małżeństwa nie można zawrzeć jeśli poprzednie małżeństwo „nie zostało nieodwołalnie rozwiązane lub unieważnione" (II,2). Niemożliwym też jest, bez względu na okoliczności (rozwód lub wdowieństwo) zawarcie czwartego małżeństwa. Takie małżeństwo jest potępiane i odrzucane (II,2).

Kościół nie udziela Sakramentu małżeństwa, osobom, które złożyły śluby zakonne. Przy tym zakazie powołuje się na kanon czwartego Soboru powszechnego (IV,6) i kanon Soboru Trulliańskiego (Trul. 44) ${ }^{16}$.

Kościół nie udziela sakramentu małżeństwa osobom, które przebywają w stanie kapłańskim (II,4). Projekt dokumentu nie wylicza stopni kapłańskich, lecz zgodnie $\mathrm{z}$ tradycją kanoniczną chodzi o biskupa, prezbitra, diakona i ipodiakona (Ap. 26, Trull. 6, 13). W Kościele prawosławnym nigdy nie istniał wymóg celibatu wobec prezbitrów, diakonów i ipodiakonów, natomiast wymaganym było i pozostaje dalej, aby kandydat do stanu duchownego zawarł związek małżeński przed przyjęciem święceń kapłańskich (Trull. 13). Żonaci biskupi w Kościele byli do VII w. Dopiero kanony soboru Trulliańskiego (692 r.)wprowadzają formalny wymóg bezżeństwa biskupów (Trull. 48).

Kolejny punkt dotyczący przeszkód w zawarciu związku małżeńskiego odnosi się do małżeństw mieszanych wyznaniowo i religijnie. Zagadnienie to jednym z najbar-

\footnotetext{
Zob. A. Znosko, Prawosławne Prawo Kościelne cz. II, Warszawa 1975, s. 75

14 Takie stanowisko wyraża Patriarchat serbski i Kościół cypryjski.

15 Kościół prawosławny zezwala na zawarcie drugiego małżeństwa, a nawet trzeciego. Drugie lub trzecie małżeństwo ma charakter pokajanny i dopuszczalne jest ze względu na ekonomię kościelną (miłosierdzie wobec człowieka). Zob. A. Znosko, dz. cyt. s. 68-69. To zagadnienie bardzo często jest niewłaściwie interpretowane, jednak na poziomie niniejszego artykułu nie będziemy w sposób szczegółowy wyjaśniać tej kwestii, ograniczymy się jedynie do stwierdzeń zawartych w omawianym dokumencie. 16 Tekst kanonów w j. polskim zob. Kanony Kościoła Prawosławnego, tłum. ks. Aleksy Znosko, Warszawa 1978.
}

dziej drażliwych punktów współczesnego życia Kościoła prawosławnego, wymaga specjalnej troski i uwagi ze strony pasterzy Kościoła. Należy stwierdzić, że dokument zawiera w sobie pewną sprzeczność. Z jednej strony zaznacza, że „małżeństwo między prawosławnymi i nieprawosławnymi nie może być zawierane, według reguł kanonicznych" (II,5a) zsyłając się na kanon 72 Soboru Trulliańskiego. $\mathrm{Z}$ drugiej zaś stwierdza się, że „może ono być zawierane ze względu na wyrozumiałość i miłość do człowieka" (II,5a). $\mathrm{W}$ dokumencie stawia się jednak warunki dla zaistnienia takiego małżeństwa. Tym warunkiem jest deklaracja ochrzczenia i wychowania dzieci zrodzonych z tego małżeństwa w wierze prawosławnej ${ }^{17}$.

W dokumencie jednoznacznie stwierdza się, że związki małżeńskie z niechrześcijanami nie mogą mieć wymiaru sakramentalnego: „Małżeństwo między prawosławnymi i niechrześcijanami lub niewierzącymi jest absolutnie zabronione według reguł kanonicznych akrybii" $(\mathrm{II}, 5 \mathrm{~b})^{18}$. W końcowej części dokumentu znajdujemy uwagę, która odnosi się znacząco do zagadnienia zarówno małżeństw mieszanych wyznaniowo jak i religijnie dając prawo poszczególnym Kościołom lokalnym stosowania zasad ekonomii względem wyżej nakreślonych przeszkód: „Stosowanie ekonomii kościelnej zostaje określone przez Święty Synod każdego autokefalicznego Kościoła prawosławnego, zgodnie z zasadami wynikającymi z kanonów kościelnych, w duchu duszpasterskiej troski o zbawienie człowieka" (II,7). Jest to ważne stwierdzenie, $\mathrm{z}$ tego względu, że różnice kulturowe i warunki geopolityczne w niektórych lokalnych Kościołach prawosławnych zasadniczo różnią się od innych Kościołów mniej zróżnicowanych wyznaniowo i religijnie. Problematyka dotycząca małżeństw mieszanych, wyznaniowo czy też religijnie poruszona została nieco wyżej, stanowi ona ważne zagadnienie i potrzebuje głębszej analizy. Ponadto w kwestii przeszkód do zawarcia związku małżeńskiego autorzy dokumentu zalecają uwzględnianie przepisów cywilnych obowiązujących w danym kraju. Nie mogą one jednak przekraczać norm przewidzianych ekonomią kościelną (II,6).

Projekt dokumentu „Sakrament małżeństwa i przeszkody do jego zawarcia", przygotowany na Wszechprawosławny Sobór stanowi ważny wkład w rozwiazywanie problemów współczesnego świata prawosławnego, ale też dotyka innych chrześcijan jak też osób nie będących chrześcijanami. Większość argumentów i wskazówek, które zostały w nim zawarte stanowią starożytną praktykę Kościoła. Nowe zagadnienia, współczesnego coraz bardziej zsekularyzowanego świata takie jak związki partnerskie czy „małżeństwa” jednej płci również znajdują swoje od-

\footnotetext{
Taka zasada nie jest swego rodzaju novum, jest ona praktykowana w wielu lokalnych Kościołach prawosławnych, jak również w Kościele rzymskokatolickim.

18 Wydaje się, że dokument przyjęty w 1982 r. był mniej rygorystyczny względem zawierania związków małżeńskich z innowiercami lub niechrześcijanami. Pozostawiał on więcej swobody lokalnym Kościołom prawosławnym na regulowanie tych spraw przez lokalne Synody lub Sobory mając na uwadze troskę pasterską. Por. Przeszkody małżeńskie. Tekst przyjęty przez II Ogólnoprawosławną Konferencję Przedsoborowa (Chambésy 1982) p. 7, T. Kałużny, Nowy Sobór Ogólnoprawosławny, dz. cyt. s. 399
} 
bicie. Stanowisko Kościoła wobec tej kwestii wydaje się być dość jednoznacznym, niemniej jednak przyjęcie takiej deklaracji na forum Ogólnoprawosławnym znacząco podnosiłoby wartość wypowiedzi. Pozostają też należy stwierdzić, zagadnienia tylko częściowo rozwiązane, chodziłoby o małżeństwa mieszane wyznaniowo i religijnie. Wydaje się, że w tej dziedzinie nie można przyjąć rozwiązań szablonowych. Niezbędnym jest branie pod uwagę kontekstu geograficznego i kulturowego, w którym żyje dany Kościół lokalny.

\section{Bibliografia}

Sakrament Małżeństwa i przeszkody do jego zawarcia, (Tekst przyjęty przez uczestników zgromadzenia (Synaxis) zwierzchników autokefalicznych Kościołów prawosławnych Chambesy 2016); tłym. Tadeusz Kałużny [w:] Przed Soborem Wszechprawosławnym, Kraków 2016, s. 267-271.

Sakrament małżenstwa i jego przeszkody, (Dokument uzgodniony przez uczestników Synaksy Zwierzchników Cerkwi Prawosławnych w Chambésy 21-28 stycznia 2016), tłum. J. Charkiewicz, J. Betlejko, A. Kuźma [w:] Wiadomości PAKP 2016, nr 5 (318), s. 14-15.

Synodica III, Secretariat pour la preparation du Saint et Grande Concile de l'Eglise Orthodoxe, Chambésy- Genève 1979.

Synodica VIII, Secretariat pour la preparation du Saint et Grande Concile de l'Eglise Orthodoxe, Chambésy- Genève 1994.
Decyzja Zwierzchników Cerkwi Prawosławnych, Wiadomości PAKP 2014, nr 4(293).

Synaksa Zwierzchników Lokalnych Cerkwi Prawosławnych, Chambésy (21-28 stycznia 2016), Wiadomości PAKP 2016, nr 3(316).

Kanony Kościoła Prawosławnego, tłum. ks. Aleksy Znosko, Warszawa 1978.

Michael Laroche, Mały Kościół, mistyczna przygoda małżeństwa, Hajnówka 2016.

Tadeusz Kałużny (ks.), Nowy Sobór Ogólnoprawosławny, Kraków 2008.

Andrzej Kuźma (ks), Trzecie spotkanie Komisji Przygotowawczej, Wiadomości PAKP 2015, nr 5 (306).

Aleksy Znosko (ks.), Prawosławne Prawo Kościelne cz. II, Warszawa 1975.

Rozmiar artykułu: 0,6 arkusza wydawniczego 